\title{
Penetapan Kadar Fenolik dan Flavonoid Hasil Ultrasonic Assisted Extraction Daun Binahong (Anredera cordifolia [Ten] Steenis)
}

\author{
Landyyun Rahmawan Sjahid ${ }^{1 *}$, Amelia Aqshari ${ }^{1}$, Sediarso ${ }^{1}$ \\ ${ }^{1}$ Fakultas Farmasi dan Sains, Universitas Muhammadiyah Prof. Dr. Hamka, Jakarta, Indonesia
}

Corresponding Author:

Landyyun Rahmawan Sjahid

landyyun@uhamka.ac.id

Received: February 2020

Accepted: March 2020

Published: March 2020

CLandyyun Rahmawan Sjahid et al. This is an openaccess article distributed under the terms of the Creative Commons Attribution License, which permits unrestricted use, distribution, and reproduction in any medium, provided the original author and source are credited.

\begin{abstract}
Anredera cordifolia [Ten] Steenis has been proven to have pharmacological activity that is thought to be influenced by the presence of phenolic compounds and flavonoids. However, both compounds are found in small concentrations through conventional extraction (maceration, decoction, soxhlet, and reflux). This study aims to prove that the ultrasonic assisted extraction method can obtain higher concentrations of phenolic and flavonoid compounds. Dried binahong leaves were extracted using ultrasonic assisted extraction with $70 \%$ ethanol. Phenolic levels were determined using Folin-Ciocalteu, while flavonoid levels were determined using the colorimetric aluminum method. The results showed binahong leaves ethanolic extract had phenolic levels of $10.16 \%$ GAE and flavonoid levels of $10.58 \%$ QE. These results are much higher than the results obtained using conventional extraction so that ultrasonic assisted extraction can be recommended to maximize the extraction of phenolic and flavonoid levels from the leaves of Binahong (Anredera cordifolia [Ten] Steenis).
\end{abstract}

Keywords: Ultrasonic assisted extraction, Anredera cordifolia [Ten] Steenis, phenolic, flavonoid

\section{Pendahuluan}

Binahong (Anredera cordifolia [Ten] Steenis) merupakan salah satu tanaman yang telah digunakan secara luas oleh masyarakat sebagai bahan obat. Beberapa kegunaannya telah didukung oleh hasil penelitian diantaranya sebagai penyembuh luka[1],[2], menurunkan kematian pada proses kelahiran ${ }^{[3]}$, analgesik ${ }^{[4]}$, anti-inflamasi ${ }^{[5]}$ anti-oksidan ${ }^{[6],[7], ~ h e p a t o-~}$ protektor $^{[8]}$, gastroprotektor ${ }^{[9]}$, nefroprotektor ${ }^{[10]}$, anti-mikroba[11]-[13], anti-diabetes ${ }^{[14],[15], ~ a n t i-~}$ hiperlipidemi[16], anti-hipertensi[17], anti-TBC[18] dan anti-kanker ${ }^{[19]}$. Aktivitas farmakologi tersebut berhubungan erat dengan metabolit sekunder yang terdapat pada Binahong seperti vitexin[20],[21], 3-hydroxy-alpha-ionone [22], stigmasterol[23], minyak atsiri[24], saponin ${ }^{[25],}$ auron $^{[26]}$, flavonol[ ${ }^{[6]}$, flavon ${ }^{[14],[27]}$ dan fenol[7].

Selama ini proses ekstraksi daun binahong dilakukan dengan metode maserasi[7],[13],[21],[28][30], dekokta[13], soklett[1], dan refluks ${ }^{[6],[10],[18]}$. Namun kuantitas dan kualitas ektrak yang diperoleh masih tergolong rendah. Kuantitas estrak dapat diketahui dari hasil rendemen yang diperoleh sebesar 1,5\% - 18\%[14],,[18],[28],[31]. Sedangkan kualitas ekstrak dapat diketahui berdasarkan kadar senyawa mayor dalam simplisia yang sebagian besar merupakan 
golongan fenol dan flavonoid dengan kadar $0,5 \%-8 \%[6],[7]$.

Perolehan kadar fenol dan flavonoid dapat ditingkatkan menggunakan ultrasonic assisted extraction. Metode ini telah terbukti meningkatkan rendemen serta kadar fenolik dan flavonoid pada ekstrak kulit jeruk dibandingkan dengan maserasi ${ }^{[32]}$, pada ekstrak Elsholtzia ciliata dibandingkan dengan maserasi, perkolasi dan refluks[33], pada ekstrak Equisetum arvense $\mathrm{L}$ dibandingkan dengan soklet ${ }^{[34]}$. Oleh karena itu, penelitian ini dilakukan untuk memberikan solusi terhadap keterbatasan perolehan kadar fenol dan flavonoid dari daun binahong (Anredera cordifolia) sehingga dapat tercapai efisiensi proses ektraksi apabila dibutuhkan dalam skala besar.

\section{Metode Penelitian}

\section{Bahan kimia}

Bahan-bahan yang digunakan dalam penelitian ini, daun binahong (Anredera cordifolia [Ten] Steenis) di peroleh dari BALITTRO, etanol $70 \%$, kertas saring, asam galat (Sigma), kuersetin (Sigma), reagen Folin-Ciocalteu, $\mathrm{NaOH}$ (Merck), natrium asetat (Merck), kalium asetat, $\mathrm{Na}_{2} \mathrm{CO}_{3}$ (Merck), kain flanel, asam asetat glasial, $\mathrm{HCl}$, reagen Meyer, serbuk $\mathrm{Mg}$, aseton, $\mathrm{FeCl}_{3}, \mathrm{NaCl}, \mathrm{H}_{2} \mathrm{SO}_{4}$, metanol, akuades.

\section{Peralatan}

Timbangan analitik (OHAUS), pengayak, ultrasonic cleaner WT-600-40, spektrofotometer $\mathrm{UV}$-Vis (shimadzu), corong pisah $100 \mathrm{ml}$ dan $500 \mathrm{ml}$, timbangan digital, oven, rotary vacum evaporator, pengayak (ABM) dan peralatan gelas lainnya.

\section{Prosedur penelitian}

Perhatikan penulisan unit pengukuran atau satuan metrik internasional dan penggunaan sub heading 3 jika diperlukan.

\section{Pembuatan ekstrak}

Serbuk daun binahong (Anredera cordifolia [Ten] Steenis) 200 gram direndam dalam etanol 70\% (1:10) pada wadah ekstraksi yang kemudian dimasukkan ke dalam ultrasonic cleaning bath dengan frekuensi $40 \mathrm{Khz}$, selama 30 menit ${ }^{[33],[35] .}$ Hasil ekstraksi disaring untuk memisahkan filtrat dan ampas. Filtrat dipekatkan menggunakan rotary evaporator pada suhu 50$60^{\circ} \mathrm{C}$ hingga diperoleh ekstrak kental. Ekstrak tersebut dihitung rendemennya, diuji organoleptik[36], kadar air[37], kadar abu total[38] dan skrining fitokimia menggunakan uji fitokimia menggunakan reagen warna yang biasa digunakan untuk masing-masing golongan metabolit sekunder yang diuji.

\section{Penetapan kadar fenol total}

Kadar fenol total ditetapkan menggunakan Folin-Ciocalteu method[39] dengan sedikit perubahan. Sebanyak $10.0 \mathrm{mg}$ ekstrak sampel dilarutkan dengan campuran metanol : akuades (1:1) sampai volume $10.0 \mathrm{ml}$. Sebanyak $300 \mu \mathrm{l}$ larutan dicampur dengan $1.5 \mathrm{ml}$ reagen Folin-Ciocalteau, didiamkan selama 3 menit, kemudian ditambah $1.2 \mathrm{ml}$ larutan $\mathrm{Na}_{2} \mathrm{CO}_{3}$ 7.5\% dan didiamkan lagi selama 35 menit pada suhu kamar. Absorbansi larutan diukur pada $767 \mathrm{~nm}$. Kadar fenol total dinyatakan sebagai ekivalen asam galat (Gallic Acid Equivalen/GAE) berdasarkan persamaan (1).

Kadar fenol $(\%$ GAE $)=\frac{\mathrm{C} \times \mathrm{V} \times \mathrm{fp} \times 10^{-6}}{\mathrm{~m}}$

Keterangan :

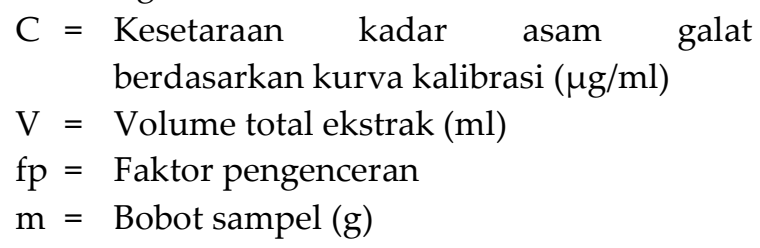

\section{Penetapan kadar flavonoid total}

Kadar flavonoid total ditetapkan menggunakan aluminium colorimetric method [40]. Sebanyak 10.0 mg ekstrak dilarutkan dalam $10.0 \mathrm{ml}$ etanol sehingga diperoleh konsentrasi 1000 ppm. Dari larutan tersebut dipipet $0.5 \mathrm{ml}$, ditambah dengan $1.5 \mathrm{ml}$ etanol $70 \%, 0.1 \mathrm{ml} \mathrm{AlCl} 310 \%, 0.1$ $\mathrm{ml}$ natrium asetat $1 \mathrm{M}$, dan $2.8 \mathrm{ml}$ aquadest. Larutan diinkubasi selama 20 menit pada suhu ruang. Absorbansi dibaca pada panjang gelombang $442 \mathrm{~nm}$. Kadar total flavonoid 
dinyatakan sebagai ekivalen kuersetin (Quercetin Equivalen/QE) berdasarkan persamaan (2).

Kadar flavonoid $(\% \mathrm{QE})=\frac{\mathrm{C} \times \mathrm{V} \times \mathrm{fp} \times 10^{-6}}{\mathrm{~m}}$

Keterangan :

$\mathrm{C}=$ Kesetaraan kadar kuersetin berdasarkan kurva kalibrasi $(\mu \mathrm{g} / \mathrm{ml})$

$\mathrm{V}=$ Volume total ekstrak $(\mathrm{ml})$

$\mathrm{fp}=$ Faktor pengenceran

$\mathrm{m}=$ Bobot sampel $(\mathrm{g})^{[40]}$

\section{Hasil dan Diskusi}

\section{Karakteristik ekstrak}

Daun binahong (Anredera cordifolia [Ten] Steenis) yang diekstraksi menggunakan ultrasonic assisted extraction menghasilkan rendemen sebesar 40.098\%. Hasil tersebut lebih besar daripada hasil ekstrak yang diperoleh menggunakan metode maserasi dan refluks, yaitu sebesar $1.5 \%$ - 18\%[14],[18],[28]. Secara organoleptis, ekstrak yang diperoleh berwarna coklat dengan bau khas dan rasa pahit. Ekstrak etanol daun binahong (Anredera cordifolia [Ten] Steenis) yang dihasilkan memiliki kadar air dan kadar abu berturut-turut sebesar $7.52 \%$ dan $3.27 \%$. Kadar air ekstrak yang dihasilkan masih memenuhi standar yaitu berada di bawah $8.85 \%\left[{ }^{[41]}\right.$. Hal ini menandakan bahwa ekstrak dapat disimpan lebih lama karena kandungan air sebagai media tumbuh mikroorganisme ada dalam jumlah terbatas sedangkan kadar abu pada ekstrak yang dihasilkan lebih dari standar yang ditetapkan, yaitu $1.64 \%{ }^{[41]}$. Tingginya kadar abu menandakan bahwa ekstrak yang dihasilkan mengandung senyawa anorganik lebih banyak daripada yang seharusnya. Senyawa ini dapat berasal dari unsur anorganik seperti logam dan mineral yang terdapat dari tanah tempat tumbuh tanaman asal. Hasil skrining fitokimia menggunakan reaksi warna menunjukkan bahwa ekstrak etanol daun binahong (Anredera cordifolia [Ten] Steenis) mengandung beberapa senyawa metabolit sekunder (tabel 1) yang sesuai dengan penelitian sebelumnya.

\section{Penetapan kadar fenol dan flavonoid total}

Penetapan kadar fenolik total dilakukan menggunakan metode Folin Ciocalteu. Pada metode ini senyawa fenol teroksidasi oleh reagen Folin Ciocalteu ${ }^{[22]}$ membentuk kompleks fosfotungstat-fosfomolibat berwarna biru dengan struktur dan mekanisme yang belum diketahui ${ }^{[43]}$. Pemberian larutan $\mathrm{Na}_{2} \mathrm{CO}_{3}$ dapat meningkatkan efisiensi reduksi fenol ${ }^{[44]}$ sehingga warna yang terbentuk menjadi lebih stabil.

Tabel 1. Hasil skrining fitokimia ekstrak etanol daun binahong (Anredera cordifolia [Ten] Steenis)

\begin{tabular}{cc}
\hline Metabolit sekunder & Hasil uji \\
\hline Fenolik & + \\
Flavonoid & + \\
Alkaloid & + \\
Tanin & + \\
Saponin & + \\
Steroid & + \\
Triterpenoid & \\
Keterangan & $(+)=$ Terdeteksi \\
$(-)=$ Tidak terdeteksi
\end{tabular}


Hasil penelitian diperoleh kadar fenol total ekstrak etanol daun binahong (Anredera cordifolia [Ten] Steenis) sebesar $10.16 \%$ GAE yang menunjukkan bahwa dalam $100 \mathrm{~g}$ serbuk simplisia terdapat $10.16 \mathrm{~g}$ senyawa fenol yang setara dengan asam galat. Asam galat digunakan sebagai pembanding karena memiliki gugus fenol yang dapat mewakili reaksi pembentukan kompleks dan memberikan warna yang stabil [42].

Penetapan kadar flavonoid total dilakukan menggunakan aluminium colorimetric method. Pada metode ini, flavonoid yang memiliki gugus orto-dihidroksi maupun hidroksi keton akan membentuk senyawa kompleks dengan logam Aluminium sehingga menghasilkan pergeseran batoktromik. Sedangkan natrium asetat digunakan untuk menstabilkan struktur dengan mengionisasi gugus 3 dan 4'-OH yang tidak terkompleks dengan $\mathrm{Al}^{3+}$ dan gugus $7-\mathrm{OH}$ sehingga struktur tetap memberikan serapan pada daerah visible [45]. Hasil penelitian diperoleh kadar flavonoid total ekstrak etanol daun binahong (Anredera cordifolia [Ten] Steenis) sebesar $10.58 \%$ QE yang menunjukkan bahwa dalam $100 \mathrm{~g}$ serbuk simplisia terdapat 10.58 g senyawa flavonoid yang setara dengan kuersetin. Kuersetin digunakan sebagai pembanding karena memiliki semua gugus $\mathrm{OH}$ yang dapat bereaksi dengan $\mathrm{Al}^{3+}$ dan natrium asetat (gambar 1).
Hasil penetapan kadar fenol dan flavonoid total (Tabel 2) menunjukkan efektifitas ultrasonic assisted extraction untuk menarik senyawa fenol dan flavonoid dari daun binahong dalam waktu yang relatif singkat (30 menit) jika dibandingkan dengan metode ekstraksi lain yang pernah diteliti.

Ultrasonic assisted extraction merupakan metode ekstraksi dengan memberikan getaran ultrasonic $>20 \mathrm{kHz}$ pada permukaan simplisia. Pada tahap tersebut, simplisia akan mengalami beberapa kondisi diantaranya fragmentasi dan erosi. Fragmentasi terjadi karena pecahnya partikel simplisia menjadi ukuran yang lebih kecil sehingga luas permukaan partikel yang diekstraksi menjadi lebih besar. Hal tersebut menyebabkan meningkatnya transfer massa dari simplisia ke pelarut dan pada akhirnya akan meningkatkan laju ekstraksi dan jumlah rendemen ${ }^{[46]}$. Hal ini tampak pada hasil rendemen penelitian ini sebesar 40.098\%. Sedangkan erosi merupakan kondisi yang terjadi akibat adanya lokalisasi getaran di setiap permukaan simplisia. Hal tersebut menyebabkan metabolit sekunder terpaksa melepaskan diri dari ikatan dalam sel sehingga meningkatkan kemampuan solvent dalam melarutkan metabolit sekunder[46].

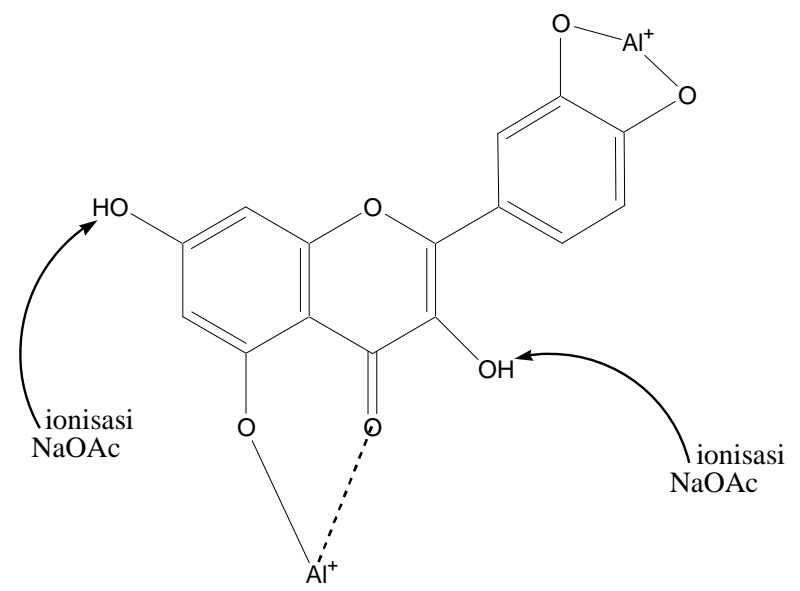

Gambar 1. Ilustrasi kompleks kuersetin - aluminium dan ionisasi natrium asetat terhadap struktur, modifikasi dari Nikolovska-Čoleska[ ${ }^{[47]}$. 
Tabel 2. Perbandingan kadar fenol dan flavonoid berdasarkan hasil penelitian dan penelitian sebelumnya

\begin{tabular}{|c|c|c|c|c|c|}
\hline $\begin{array}{l}\text { Metode } \\
\text { ekstraksi }\end{array}$ & $\begin{array}{l}\text { Pelarut } \\
\text { ekstrak }\end{array}$ & $\begin{array}{c}\text { Rendemen } \\
(\%)\end{array}$ & $\begin{array}{c}\text { Kadar fenol } \\
\text { total } \\
\text { (\% GAE) }\end{array}$ & $\begin{array}{c}\text { Kadar } \\
\text { flavonoid } \\
\text { total } \\
(\% \text { QE) }\end{array}$ & Literatur \\
\hline Ultrasonik & Etanol 70\% & 40.098 & 10.16 & 10.58 & \\
\hline Maserasi & Etanol 70\% & 11.40 & nd & nd & [21] \\
\hline Maserasi & Etanol 96\% & 12.32 & nd & 1.35 & [21] \\
\hline Maserasi & Etanol & nd & 2.843 & nd & [29] \\
\hline Maserasi & Etanol p.a & 3.29 & nd & 0.001 & [30] \\
\hline Refluks & Etanol 70\% & nd & 8.42 & 0.70 & {$[6]$} \\
\hline
\end{tabular}

Efek dari proses erosi tersebut mengakibatkan terlarutnya fenol dan flavonoid dalam kondisi optimal dengan kadar masing-masing sebesar $10.16 \%$ GAE dan 10.58 \%QE. Selain itu, ultrasonic assisted extraction pada penelitian ini dilakukan pada suhu kamar sehingga dapat meminimalkan kerusakan atau degradasi senyawa metabolit sekunder yang diekstrak.

\section{Kesimpulan}

Berdasarkan hasil penelitian, maka metode ultrasonic assisted extraction dapat menjadi solusi atas rendahnya kadar fenol dan flavonoid yang terekstrak pada saat menggunakan metode ekstraksi konvensional dan metode ini dapat diterapkan untuk industri obat tradisional untuk mendapatkan ekstrak daun binahong (Anredera cordifolia [Ten] Steenis) dengan kualitas yang lebih baik.

\section{Daftar Pustaka}

1. Wijayanti, K. \& Esti, R. H. S., Effectiveness of binahong decoction water (Anredera cordifolia (Ten.) Steenis) for perineal wound healing at home delivery aesya grabag Magelang, Indonesia. Int. J. Res. Med. Sci., 5(5): 1970-1975 (2017).

2. Sutrisno, E., Sukandar, E., Fidrianny, I. \&
Adnyana, I. K., Wound healing in vivo and in vitro study of binahong leaves (Anredera cordifolia (ten.) Steenis) and pegagan (Centella asiatica (L.) Urban) ethanolic extract. Pharmacol. OnLine, 1: 111-116 (2018).

3. Wijayanti, D., Setiatin, E. T. \& Kurnianto, E., Leucocyte profile and offspring production of Guinea pig (Cavia cobaya) given Anredera cordifolia leaf extract. J. Indones. Trop. Anim. Agric., 43(1): 19-25 (2018).

4. Yuziani., Harahap, U. \& Karsono., Evaluation of analgesic activities of ethanolic extract of Anredera cordifolia (Ten.) v. Steenis leaf. Int. J. PharmTech Res., 6(5): 1608-1610 (2014).

5. Sutrisno, E., Adnyana I, K., Yulinah Sukandar, E., Fidrianny, I. \& Aligita, W., Anti-inflammatory study of Anredera cordifolia leaves and Centella asiatica herbs and its combinations using human red blood cell-membrane stabilization method. Asian J. Pharm. Clin. Res., 9(5): 7880 (2016).

6. Fidrianny, I., Wirasutisna, K. R. \& Amanda, P., Senyawa antioksidan dari ekstrak etil asetat daun binahong (Anredera cordifolia (Ten.) Steenis) dari 
Babakan Ciparay, Bandung Selatan, Indonesia. Acta Pharm. Indones., 38(1): 2630 (2013).

7. Susanti, H., Total phenolic content and antioxidant activities of binahong (Anredera cordifolia.). J. Kedokt. dan Kesehat. Indones. (Indonesian J. Med. Heal., 10(2): 171-175 (2019).

8. Estowo, R., Zulfian. \& Tjiptaningrum, A., The effect of binahong leaves extraction (Anredera Cordifolia (Ten.) Steenis) in 70 $\%$ ethanol toward ALT activities of male rat (Rattus norvegicus) of Sprague dawley which has induced by ethanol $50 \%$. Majority, 3(6): 108-117 (2014).

9. Wibhisono, H., Busman, H. \& Susantiningsih, T., Efek protektif ekstrak etanol daun binahong (Anredera cordifolia (Ten.) Steenis) terhadap gambaran histopatologi lambung tikus putih galur Sprague dawley yang diinduksi etanol. Majority, 3(6): 170-178 (2014).

10. Sukandar, E. Y., Fidrianny, I. \& Adiwibowo, L. F., Efficacy of ethanol extract of Anredera cordifolia (Ten.) Steenis leaves on improving kidney failure in rats. Int. J. Pharmacol., 7(8): 850-855 (2011).

11. Leliqia, N. P. E., Sukandar, E. Y. \& Fidrianny, I., Antibacterial activities of Anredera cordifolia (Ten.) v. Steenis leaves extracts and fractions. Asian J. Pharm. Clin. Res., 10(12): 10-13 (2017).

12. Basyuni, M., Ginting, P. Y. A. B. \& Lesmana, I., Phytochemical analysis of binahong (Anredera cordifolia) leaves extract to inhibit in vitro growth of Aeromonas hydrophila. in Proceedings of the 3rd International Symposium on Applied Chemistry, 1904: 020072-1-020072-5 AIP Publishing, (2017).

13. Elyani, H. \& Risandiansyah, R., Antibacterial potential of four herbal plants (Syzygium cumini, Piper ornatum, Anredera cordifolia, and Alpinia galangan) against Staphylococcus aureus and Escherichia coli. JIMR - J. Islam. Med. Res., 1(2): 26-33 (2017).
14. Djamil, R., Winarti, W., Zaidan, S. \& Abdillah, S., Antidiabetic activity of flavonoid from binahong leaves (Anredera cordifolia) extract in alloxan induced mice. J. Pharmacogn. Nat. Prod., 03(02): 139 (2017).

15. Astuti, S. M., Sakinah, A. M. M. \& Risch, A., The triterpenoid saponin from binahong [Anredera cordifolia (Ten) Steenis] to potential using as antidiabetic activity in animal laboratory. in International Conference on Drug Development of Natural Resources, 331-344 (2012).

16. Lestari, D., Sukandar, E. Y. \& Fidrianny, I., Anredera cordifolia leaves extract as antihyperlipidemia and endothelial fat content reducer in male Wistar rat. Int. J. Pharm. Clin. Res., 7(6): 435-439 (2015).

17. Garmana, A. N., Sukandar, E. Y. \& Fidrianny, I., Antihypertension study of Anredera cordifolia (Ten.) v. Steenis extract and its fractions in rat through dexamethasone induction and nitric oxide release. Asian J. Pharm. Clin. Res., 11(1): 278-282 (2018).

18. Pitaloka, D. A. E. \& Sukandar, E. Y., Synergistic study on n-hexane extract of Anredera cordifolia (Ten.) v Steenis (binahong) leaves combined with antituberculosis drugs against drugsensitive and drug-resistant of Mycobacterium tuberculosis. J. Appl. Pharm. Sci., 8(5): 134-138 (2018).

19. Virginia, D. M., Saputra, R. P. \& Setiawati, A., Cytotoxic activity of Anredera cordifolia leaf extract on Hela cells. Biotropia (Bogor)., 26(1): 33-40 (2019).

20. Mulia, K., Muhammad, F. \& Krisanti, E., Extraction of vitexin from binahong (Anredera cordifolia (Ten.) Steenis) leaves using betaine - 1,4 butanediol natural deep eutectic solvent (NADES). in International Conference on Chemistry, Chemical Process and Engineering (IC3PE), 1823: 020018-1020018-4 (2017).

21. Dwitiyanti., Harahap, Y., Elya, B. \& Bahtiar, A., Impact of solvent on the characteristics of standardized binahong leaf (Anredera cordifolia (Ten.) Steenis). 
Pharmacogn. J., 11(6): 1463-1470 (2019).

22. Bari, I. N., Kato-Noguchi, H., Iwasaki, A. \& Suenaga, K., Allelopathic potency and an active substance from Anredera cordifolia (Tenore) Steenis. Plants, 8(134): 1-9 (2019).

23. Manik, Y., Fachriyah, E. \& Kusrini, D., Isolasi, identifikasi dan uji sitotoksik senyawa steroid dari daun binahong (Anredera cordifilia (Ten.) Stennis). J. Kim. Sains dan Apl., 16(1): 23-26 (2013).

24. Souza, L. F., Barros, I. B. I. de., Mancini, E., Martino, L. De., Scandolera, E. \& Feo, V. De., Chemical composition and biological activities of the essential oil from Anredera cordifolia grown in Brazil. Nat. Prod. Commun., 9(7): 1003-1006 (2014).

25. Astuti, S. M., Sakinah A.M, M. S., Andayani B.M, R. \& Risch, A., Determination of saponin compound from Anredera cordifolia (Ten) Steenis plant (binahong) to potential treatment for several diseases. J. Agric. Sci., 3(4): 224-232 (2011).

26. Veronita, F., Wijayati, N. \& Mursiti, S., Isolasi dan uji aktivitas antibakteri daun binahong serta aplikasinya sebagai hand sanitizer. Indones. J. Chem. Sci., 6(2): 138144 (2017).

27. Djamil, R., Wahyudi, P., Wahono, S. \& Hanafi, M., Antioxidant activity of flavonoid from Anredera cordifolia (Ten) Steenis leaves. Int. Res. J. Pharm., 3(9): 241243 (2012).

28. Djamil, R., Winarti, W., Syamsudin. \& Rasna, M., Standardization and Aglucosidase inhibitory of extract from Anredera cordifolia leaves. in Proceedings of The 9th Joint Conference on Chemistry, 317-321 (2015).

29. Hasri., Anwar, M. \& Karim, M., Analisis fenolik dan daya hambat daun binahong (Anredera cordifolia (Ten.) Steenis) terhadap bakteri Eschericia coli dan Staphylococcus aureus. Indones. Chem. Appl. J., 1(1): 1-9 (2017).

30. Selawa, W., Runtuwene, M. R. J. \& Citraningtyas, G., Kandungan flavonoid dan kapasitas antioksidan total ekstrak etanol daun binahong [Anredera cordifolia (Ten.) Steenis.]. Pharmacon J. Ilm. Farm. UNSRAT, 2(1): 18-22 (2013).

31. Susanty. \& Yudhistirani, S. A., Pengaruh waktu ekstraksi daun binahong (Anredera cordifolia (Tenore) Steenis) terhadap kemampuan daya hambat bakteri Escherichia coli untuk pembuatan hand sanitizer. J. Konversi, 7(1): 1-10 (2018).

32. Nipornram, S., Tochampa, W., Rattanatraiwong, P. \& Singanusong, R., Optimization of low power ultrasoundassisted extraction of phenolic compounds from mandarin (Citrus reticulata Blanco cv. Sainampueng) peel. Food Chem., 241: 338-345 (2018).

33. Pudziuvelyte, L., Jakštas, V., Ivanauskas, L., Laukevičienè, A., Ibe, C. F. D., Kursvietiene, L. \& Bernatoniene, J., Different extraction methods for phenolic and volatile compounds recovery from Elsholtzia ciliata fresh and dried herbal materials. Ind. Crops Prod., 120: 286-294 (2018).

34. Oniszczuk, A., Podgórski, R., Oniszczuk, T., Zukiewicz-Sobczak, W., Nowak, R. \& Waksmundzka-Hajnos, M., Extraction methods for the determination of phenolic compounds from Equisetum arvense L. herb. Ind. Crops Prod., 61: 377-381 (2014).

35. Winata, E. W. \& Yunianta., Ekstraksi antosianin buah murbei (Morus alba L.) metode ultrasonic bath (kajian waktu dan rasio bahan : pelarut). J. Pangan dan Agroindustri, 3(2): 773-783 (2015).

36. Departemen Kesehatan Republik Indonesia., Buku panduan teknologi ekstrak. Direktorat Jenderal Pengawasan Obat dan Makanan, (2000).

37. Pasaribu, G., Gusmailina., Komarayati, S., Zulnely. \& Dahlian, E., Analisis senyawa kimia Dryobalanops aromatica. J. Penelit. Has. Hutan, 32(1): 21-26 (2014).

38. Departemen Kesehatan Republik Indonesia., Farmakope herbal indonesia. Direktorat Jenderal Pengawasan Obat dan Makanan, (2008).

39. Siddiqui, N., Rauf, A., Latif, A. \& 
Mahmood, Z., Spectrophotometric determination of the total phenolic content, spectral and fluorescence study of the herbal Unani drug Gul-e-Zoofa (Nepeta bracteata Benth). J. Taibah Univ. Med. Sci., (2017).

doi:10.1016/j.jtumed.2016.11.006

40. Chang, C.-C., Yang, M.-H., Wen, H.-M. \& Chern, J.-C., Estimation of total flavonoid content in propolis by two complementary colorimetric methods. J. Food Drug Anal., 10(3): 178-182 (2002).

41. Kementrian Kesehatan RI., Farmakope herbal indonesia. Kementrian Kesehatan RI, (2011).

42. Singleton, V. L., Orthofer, R. \& LamuelaRaventós, R. M., Analysis of total phenols and other oxidation substrates and antioxidants by means of folin-ciocalteu reagent. Methods Enzymol., 299: 152-178 (1999).

43. Schofield, P., Mbugua, D. M. \& Pell, A. N., Analysis of condensed tannins : a review. Anim. Feed Sci. Technol., 91: 21-40 (2001).

44. Chen, L. Y., Cheng, C. W. \& Liang, J. Y.,
Effect of esterification condensation on the Folin-Ciocalteu method for the quantitative measurement of total phenols. Food Chem., 170: 10-15 (2015).

45. Cornard, J. P. \& Merlin, J. C., Complexes of aluminium (III) with isoquercitrin : spectroscopic characterization and quantum chemical calculations. Polyhedron, 21: 2801-2810 (2002).

46. Chemat, F., Rombaut, N., Sicaire, A. G., Meullemiestre, A., Fabiano-Tixier, A. S. \& Abert-Vian, M., Ultrasound assisted extraction of food and natural products. mechanisms, techniques, combinations, protocols and applications. A review. Ultrasonics Sonochemistry, 34: 540-560 (2017).

47. Nikolovska-Čoleska, Ž., Dorevski, K., Klisarova, L. \& Šuturkova-Milošević, L., Identification of phenolic constituents isolated from Macedonian propolis. Bull. Chem. Technol. Maced., 14(1): 13-17 (1995). 